\title{
Using Online Translators in the Second Language Classroom: Ideas for Advanced- level Spanish
}

Elizabeth ENKIN*

Errapel MEJIAS-BIKANDI*

\begin{abstract}
In this paper, we discuss the benefits of using online translators in the foreign language classroom. Specifically, we discuss how faulty online translator output can be used to create activities that help raise metalinguistic awareness of second language grammar and of the differences between grammatical constructions in the first and second language, which can help with the language learning process. Specific structures for advanced-level Spanish that produce faulty online translator output are explained, and then we provide sample editing-type activities for these structures, as well as anecdotal evidence regarding students' reactions to these tasks. Although the activities discussed are specifically designed for Spanish, they may also be used as a model for other languages. Importantly, these activities may prove helpful for Spanish teachers because these structures are covered in many university-level advanced Spanish grammar courses. These types of activities could also ultimately help students who will be seeking translation-oriented jobs.
\end{abstract}

Keywords: Online translators; editing online translator output; advanced-level Spanish learning; metalinguistic awareness; learning subordinate clauses in Spanish.

* University of Nebraska-Lincoln, United States

Corresponding author: eenkin@unl.edu

Received: 2015-06-06 / Sent for peer review: 2015-06-12 / Accepted by peers: 2015-09-01 / Approved: 2015-11-09

To reference this article in APA style / Para citar este artículo en APA / Para citar este artigo

Enkin, E. \& Mejías-Bikandi, E. (2016). Using online translators in the second language classroom: Ideas for

advanced-level spanish. LACLIL, 9(1), 138-158. doi:10.5294/laclil.2016.9.1.6 


\title{
Uso de traductores en línea en la clase de una segunda lengua: ideas para español de nivel avanzado
}

\begin{abstract}
Resumen
En este artículo se discuten los beneficios de utilizar traductores en línea en la clase de lengua extranjera. Específicamente, se describe cómo se pueden utilizar resultados incorrectos del traductor en línea para crear actividades que ayuden a crear conciencia metalingüística sobre la gramática de la segunda lengua y las diferencias entre las construcciones gramaticales entre la primera y la segunda lengua, lo cual puede ser de ayuda en el proceso de aprendizaje. Se explican estructuras específicas del español de nivel avanzado que producen resultados incorrectos en el traductor; posteriormente, se suministran muestras de actividades de edición para estas estructuras, así como evidencia anecdótica relacionada con la reacción de los estudiantes ante estas tareas. Aun cuando las actividades presentadas están diseñadas específicamente para español, también pueden ser utilizadas como modelo para otras lenguas. Cabe anotar que estas actividades podrían ser útiles para profesores de español, ya que estas estructuras se cubren en muchos cursos de gramática del español a nivel avanzado. Igualmente, estas actividades podrían ser de utilidad para estudiantes interesados en trabajos relacionados con traducción.
\end{abstract}

Palabras clave: traductores en línea; edición de resultados del traductor en línea; aprendizaje de español a nivel avanzado; conciencia metalingüística; aprendizaje de cláusulas subordinadas en español. 


\title{
Uso de tradutores on-line na aula de uma segunda língua: ideias para espanhol de nível avançado
}

\begin{abstract}
Resumo
Neste artigo, discutem-se os benefícios de utilizar tradutores on-line na aula de língua estrangeira. Especificamente, descreve-se como podem ser utilizados resultados inadequados do tradutor on-line para criar atividades que ajudem a conscientizar metalinguisticamente sobre a gramática da segunda língua e as diferenças entre as construções gramaticais entre a primeira e a segunda língua, o que pode favorecer o processo de aprendizagem de língua. Explicam-se estruturas específicas do espanhol de nível avançado que produzem resultados inadequados no tradutor; em seguida, fornecem-se amostras de atividades de edição para essas estruturas, bem como evidências quanto à reação dos estudantes diante dessas tarefas. Cabe destacar que essas atividades podem ser úteis para professores de espanhol, já que essas estruturas estão presentes em muitos cursos de gramática de espanhol avançado. Também, elas podem ser usadas com estudantes interessados em trabalhos relacionados com tradução e como modelo para o ensino de outras línguas, ainda que tenham sido pensadas para espanhol.
\end{abstract}

Palavras-chave: tradutores on-line; edição de resultados do tradutor on-line; aprendizagem de espanhol de nível avançado; consciência metalinguística; aprendizagem de orações subordinadas em espanhol. 


\section{INTRODUCTION}

Researchers have noted that second language (L2) educators may be wary of online translators (OTs), as they are seen as tools that provide learners with shortcuts that may negatively affect their L2 acquisition (Correa, 2014; Luton, 2003; Williams, 2006). However, it is also true that, currently, the translations generated by OTs are imperfect and frequently contain errors. In the case of translations from English into Spanish, there are not only frequent agreement or vocabulary errors, but also mistakes that relate to the different syntactic manifestation in both languages of equivalent grammatical constructions. Indeed, occasionally the mistakes not only result in an ungrammatical text, but also substantially change the meaning of the original fragment. These frequent mistranslations make these tools somewhat unreliable, and the translations they generate often need to be edited.

In one of the most recent articles on the topic, Correa (2014) has discussed how OTs could in fact be used as a pedagogical tool in the L2 Spanish classroom, rather than viewed as a form of cheating. The author explains that OTs could be used as a tool to raise metalinguistic awareness, as well as metalinguistic awareness of grammatical differences between the L1 (English) and L2 (Spanish), and points to several examples where OTs generate imperfect translations, and thus could be useful for the classroom, where learners can edit this output (and the input). For example, OTs can produce errors in long distance adjective agreement and verb conjugation, and the use of the subjunctive, as well as errors that require more thought, such as word-structure in English as compared to Spanish.

We agree with Correa (2014) that the fact that these translations need to be edited turns OTs into an effective pedagogical tool to be used in the L2 classroom, which has also been proposed elsewhere (e.g. Garcia \& Pena, 2011; Niño, 2009; Williams, 2006). We believe that the explicit discussion and analysis of errors made by OTs may be used to raise metalinguistic awareness of the L2 (Spanish in our case) and of grammatical differences between the L1 (English in our case) and L2 (Spanish). This heightened grammatical awareness may in turn result in a firmer grasp of the grammatical 
constructions in both languages. Thus, in this paper, we share some ideas on how to use OTs specifically in an advanced L2 Spanish grammar course that compares subordinate clauses in English and in Spanish. We illustrate their use to direct the learners' attention to the different manifestation in both languages of nominal complements, relative clauses, adverbial clauses, and sentence connectors.

\section{The Use of Online Translators in Language Learning: Raising Me- talinguistic Awareness}

As discussed above, OTs could be used in the L2 classroom to raise metalinguistic awareness. Renou (2001) provides a broad definition of metalinguistic awareness of an L2 as the “...conscious knowledge of the formal aspects of the target language (e.g. grammar)” (p. 248), and overall, metalinguistic knowledge can be defined as the explicit (conscious) knowledge of how a language works (Bialystok, 1979). Roehr (2007) also explained that L2 metalinguistic knowledge has traditionally been defined as “...learners' ability to correct, describe, and explain faulty [L2] sentences” (p. 174). Several studies have shown benefits of possessing metalinguistic knowledge, and specifically that L2 proficiency and metalinguistic knowledge can be correlated. In a recent example, Alipour (2014) tested first and second-year English as a foreign language (EFL) university-level students, and found a positive correlation between their metalinguistic knowledge (i.e. their ability to correctly describe, explain, and change underlined errors in L2 sentences) and their L2 linguistic knowledge as seen through a cloze task. In another study, Correa (2011) tested Spanish learners ranging from beginner to advanced levels, and found a strong, positive correlation between metalinguistic knowledge and use of the subjunctive in Spanish on fill-inthe-blank, forced choice, sentence completion, and open-ended tasks (here, metalinguistic knowledge was operationalized as both the knowledge of grammar terminology in the L1 and L2, and explicit knowledge about L1 and L2 grammar rules). ${ }^{1}$

1 It should be pointed out that some studies have found different results - e.g. for a weak correlation between metalinguistic knowledge and language proficiency see Alderson, Clapham, \& Steel, 1997; for mixed results see Renou, 2001). 
Following the above definitions, and as recently suggested also by Correa (2014), one way to help raise metalinguistic awareness is by editing the faulty L2 output of an OT (although Correa also notes that "pre-editing" both first language (L1) input or L2 input could be useful as well). Editing a classmate's written work, or "peer editing", has been discussed as a useful activity in language learning classrooms that can aid the writing process (e.g. Byrd, 2003; Hansen \& Liu, 2005), and that can ultimately help improve a final written product (Berg, 1999). There is however the question of how useful peer review is for the editor as compared to the writer, or "editee" (i.e. the student whose paper is being edited). One study has specifically looked at the effectiveness of peer review for the editor in the L2 classroom: Lundstrom and Baker (2009) found that English language learners (those who were beginner and intermediate-level, and specifically who had not had or had very little prior peer review experience) who served exclusively as "editors" improved their writing significantly more over the course of one semester as compared to learners who had only received peer feedback. Thus, their study suggests that peer review might be more useful for the editor, since the editing process can help learners critically reflect on language. Moreover, critically reflecting on language in this way may lead to conversations about L1-L2 comparisons, thereby helping students learn the L2 through the L1. Using OTs in this way could, as Burton (2003) suggested, assist in implementing the comparisons standard (specifically standard 4.1) outlined in the Standards for Foreign Language Learning (now the reworked "World-Readiness Standards for Learning Languages") (National Standards, 2015).

\section{The Use of Online Translators in the Classroom: L2 Learning Activities}

Pre-editing (the revision of a source text such that it will produce an adequate machine/OT translation), and post-editing (revising machine translation/OT output) are two activities that have been discussed in the literature on machine translation/OT use with foreign language students (e.g. Correa, 2014; French, 1991; Garcia \& Pena, 2011; Niño, 2008, 2009; Kliffer, 2005; Richmond, 1994; Shei, 2002; Somers, 2003). Several of these researchers have discussed their experiences with using these types of learning activities. 
Of specific interest to the present paper, however, is the research done with post-editing/correcting L2 output, since our focus is on how activities can help raise L2 metalinguistic awareness (as defined above), which can then be extended to highlighting differences in the L1 and L2. Indeed, in an article assessing the merit of post-editing machine translation L2 output (as compared to traditional translating), Niño (2008) noted that

...if the teacher controls the input text in such a way that the MT [machine translation] output errors are relevant and appropriate for the students, post-editing into the foreign language can provide an excellent form-focused activity that can help the students develop their grammatical and lexical accuracy. (p. 42).

Several studies in recent years have found benefits of post-editing an OT's L2 output. For example, Niño (2009) examined survey (qualitative) data on student perceptions of machine translation post-editing, and particularly of OT post-editing (students were advanced-level Spanish learners who had taken a ten-week course focusing on machine translation and post-editing of machine translation). Of note, the author's results show that $81 \%$ of learners thought that machine translation helped improve their L2: they explained that post-editing helped them detect errors and assisted their skills of L2 correction, promoted reflection on L2 errors they make, aided their comprehension skills, and helped them be more focused on language use as well as accuracy. Student comments further indicated that the post-editing experience helped them to develop language awareness, be more accurate in the L2, and be more fluent in writing. Interestingly, O'Neill (2012) examined the effect of OT use for writing in third and fourth semester French students, and found that OT use did not have a negative impact on L2 writing, and might actually have a positive influence.

\section{Present Contribution}

In the remainder of this article, we first discuss the types of faulty output that an OT would produce for three target Spanish structures of interest (discussed below). These structures are generally covered in an advanced-level Spanish grammar course (see for instance, Butt \& Benjamin, 
2004; Campos, 1993; Koike \& Klee, 2012; Larousse, 2010; Lunn \& DeCesaris, 2006; Whitley \& González, 2007). In fact, the second author of this article teaches a 400-level Spanish grammar course at a large research university in the United States Midwest, and these structures are key topics that are covered. At the end of the next section we have included a table showing a sample format for possible class activities involving OT post-editing for these structures (these activities were and are used in the author's grammar course). Since these types of structures are typically covered in grammar courses of this level, the explanation and subsequent activities may be helpful for Spanish language educators (the activities could be used as a model when teaching other languages as well). In these sample activities, errors in the OT output are pointed out to students, and then as part of the task, students are asked to post-edit as well as explain how and why they would revise the OT's L2 (Spanish) grammar mistakes (they are also asked to make relevant connections to English, their L1). This is important given that these types of exercises (i.e. providing corrections and overt explanations) require students to use explicit knowledge of language (Bialystok, 1981). Lastly, we also briefly discuss the second author's anecdotal experience with using these types of activities in the classroom.

\section{Structures of Interest and Online Translations}

In this section, we discuss three structures of interest-nominal complements, relative clauses, and adverbial clauses - where online translations can be used to highlight grammatical errors for students. Google Translate was used as the OT, and the translations that are provided were produced between June 2014 and August 2015. Some of the original fragments in English were created by the authors. In cases where the original text in English was taken from an online news source, the source has been identified in the text. We also believe that by using Google Translate, this paper will be applicable for many readers. This is because the majority of OT usage occurs with ones that are free to use, such as Google Translate (Garcia \& Pena, 2011). Lastly, one important caveat to note, however, is that OTs are becoming increasingly better at producing the correct output. Foreign language educators should therefore keep in mind that materials may need to be updated as necessary as time goes on. 


\section{Nominal Complements}

A nominal complement is a subordinate clause that plays grammatical roles that are characteristic of nouns. Generally, nominal clauses act as complements of verbs, either as an object complement, as in (1), or as a subject complement, as in (2). We use brackets to identify the subordinate clause in Spanish:

(1) Queremos [que nos digan la verdad]. We want them to tell us the truth.

(2) Es importante [que nos digan la verdad]. It is important that they tell us the truth.

Editing of translations generated by OTs is effective in highlighting at least two specific differences between Spanish and English nominal clauses:

i. there are non-finite complements in English that require a conjugated verb in Spanish, and

ii. a complement verb in Spanish may appear in the indicative or the subjunctive mood, whereas such distinction is not encoded in the form of complement verbs in English.

As an illustration of the first phenomenon, consider the following original sentence in English and the translation generated by the OT. In these examples, we include the original fragment in English (a), the OT output (b), and the correct translation for the underlined part (c):

(3) a. We got into a taxi and asked the taxi driver to drive as quickly as he could so we would arrive on time.

b. Metimos en un taxi y le preguntamos al conductor que conducir tan rápido como pudo así que iba a llegar a tiempo.

c. Nos metimos en un taxi y le pedimos al conductor que condujera.

In this case, the underlined part illustrates a verb that takes a non-finite (infinitive) complement in English (to drive). The OT incorrectly generates a construction in Spanish where the non-finite complement appears also as an infinitive in Spanish. As a class activity, a student would be expected to edit this part and correctly conjugate the complement verb in the subjunctive. 
Notice also that this pattern (VERB+OBJECT PRONOUN+INFINITIVE) is quite productive in English (complements of verbs such as want, advise, prefer, etc.), and in most cases the corresponding complement in Spanish will require a conjugated verb in the subjunctive. As part of the class activity associated with this example (see Table 1 for sample activities), the student is required to identify the pattern in English and associate it with the correct equivalent structure in Spanish. This will in turn direct the students' attention to this grammatical construction in English and its equivalent in Spanish.

A slight variation of this pattern is illustrated in (4), where the notional subject of the non-finite verbal complement in English is introduced by a preposition:

(4) a.It's a real honor for them to think that highly of me.

b. Es un verdadero honor para ellos pensar que muy bien de mí.

c. Es un verdadero honor que piensen tan bien de mí.

Again, in this case the OT does not conjugate the complement verb in Spanish. In fact, the OT fails to identify the underlined expression as a nominal complement at all, and it proposes a word-for-word translation, the result being close to uninterpretable.

Other cases would require students to correctly identify nominal clauses with a conjugated verb in English, and select the appropriate verbal mood in Spanish. As an example, consider (5) below:

(5) a. That a corpse lies on the street may not shock. What is remarkable is that on a downtown street in a major city, a corpse can decompose for days, like carrion, and that is acceptable. (adapted from The New York Times, Sept. 8, 2005)

b. Que un cadáver se encuentra en la calle puede no sorprender. Lo notable es que en una calle del centro de una gran ciudad, un cadáver puede descomponerse durante días, como carroña, y que es aceptable.

c. Que un cadáver se encuentre en la calle puede no sorprender. Lo notable es que en una calle del centro de una gran ciudad, un cadáver pueda descomponerse durante días, como carroña, y que eso sea aceptable.

The underlined expressions illustrate nominal clauses whose verb in Spanish would naturally appear in the subjunctive (as the complement 
of the comment predicates sorprender, and es notable). In this case, the OT generated a translation where the verbs are all conjugated in the indicative mood. Notice also the word order in the first sentence in (5), where the main predicate appears in sentence final position. Correcting this mistake would require that students are aware of the syntactic structure of the sentence, correctly identifying the complement and main predicate.

\section{Relative Clauses}

An adjective or relative clause is a subordinate clause that plays the grammatical role of an adjective, modifying a noun (the antecedent). Adjective clauses in Spanish contain a relative pronoun, which agrees with the antecedent, and fulfills the grammatical role of the antecedent within the relative clause. Sentences (6) and (7) illustrate relative clauses in Spanish. The underlined element is the relative pronoun:

(6) Compré los libros [que necesitaba].

I bought the books that I needed.

(7) Estos son los amigos [con los que me quedé] cuando fui de vacaciones.

These are the friends I stayed with when I was on vacation.

Activities involving relative clauses seek to highlight two differences in the form of this construction in English and Spanish:

i) a preposition may appear at the end of a relative clause in English, but not in Spanish, and

ii) there are different conditions for the use of relative pronouns in English and Spanish.

Consider the example in (8):

(8) a. You want someone to read your profile and for them to think that you are someone that they would be interested to find out more about.

b. Quieres que alguien lea su perfil y para que ellos piensan que usted es alguien que estarían interesados en saber más acerca de.

c. Quieres que alguien lea su perfil y que piensen que usted es alguien acerca de quien estarían interesados en saber más.

The underlined part of the English original is a relative clause. Notice that the preposition about appears at the end of the clause. The OT 
has maintained this preposition at the end, and the resulting sentence is ungrammatical in Spanish. The use of relative pronouns in Spanish depends also on whether it appears as the complement of a preposition, as is the case in the example above. Thus the student in this case would not only be expected to form the prepositional expression acerca de, but also to change the relative pronoun (from que to quien or el que). ${ }^{2}$

As another example, consider (9) below:

(9) a. "It's probably the most important thing in your cancer care that you believe someone has your best interests at heart," said the doctor, director of the melanoma program at the New York University Cancer Institute. "In an area where there are no right answers, you're going to get a different opinion with every doctor you see. You've got to find a doctor you feel most comfortable with, the one you most trust." (adapted from The New York Times, Sept. 30, 2008)

b. "Es probablemente la cosa más importante en su tratamiento del cáncer que usted cree que alguien tiene sus mejores intereses en el corazón", dijo la doctora, director del programa de melanoma en el Instituto de Cáncer de la Universidad de Nueva York. "En una zona donde no hay respuestas correctas, usted va a obtener una opinión diferente con cada médico que vea. Tienes que encontrar a un doctor que se sienta más cómodo, el que más confianza."

c. "Tienes que encontrar un médico con el que te sientas muy cómodo, aquel en el que más confíes."

The underlined portions show two relative clauses. In this case, the OT has ignored the prepositions altogether, and in doing so it has significantly altered the meaning of the original text. ${ }^{3}$ These examples also illustrate a common pattern in English, and a construction with which advanced students of Spanish typically struggle. Editing OT output highlights this

2 The example in (8) also contains a nominal construction similar to the one illustrated in (4) (...for them to think that you are someone...), and which the translator incorrectly identifies as a purpose adverbial clause.

3 The translation offered for the first relative clause is equivalent to: "a doctor that feels most comfortable". 
pattern and its Spanish equivalent, thus increasing the students' metalinguistic awareness of L1-L2 differences.

Examples (10) and (11) illustrate errors in the translation of relative pronouns when the antecedent is with a clause (10) or a word such as nada, algo, esto, eso, todo, aquello:

(10) a. Jeremy recounts head-butting the reef at Lakey Peak, which resulted in 35 stitches and two hours of memory loss. (adapted from www.surfline.com, June 29, 2015)

b. Jeremy relata cabezazo del arrecife en Lakey Peak, que se tradujo en 35 puntos y dos horas después de la pérdida de memoria. c. lo que se tradujo en 35 puntos y dos horas de pérdida de memoria.

(11) a. I was told there is absolutely nothing they could help me with, no treatment. (The New York Times, Sept. 30, 2008)

b. Me dijeron que no hay absolutamente nada que me podía ayudar con, ningún tratamiento.

c. Me dijeron que no hay absolutamente nada con lo que me pudieran ayudar.

Sentence (10) illustrates a type of relative clause where the antecedent of the relative pronoun which is in fact the previous sentence. In this case, the correct relative pronoun in Spanish would be lo que or lo cual, rather than que. In (11) the preposition appears at the end of the relative clause in the Spanish translation, as in (8), but notice also that, once the preposition is fronted, the relative pronoun in Spanish should be lo que, or lo cual, since in this case the antecedent is nada.

\section{Adverbial Clauses}

Adverbial clauses play the role of adverbs within a sentence: they function as adjuncts that typically modify a verbal predicate. A conjunction or conjunctive expression (clause connector) connects the adverbial clause with the predicate. This connector establishes also a semantic or meaning relation between the subordinate clause and the main predicate. Depending on the semantic relation that is established by the connector, different types of adverbial clauses are identified: time, manner, cause, concessive, 
conditional, consecutive, of purpose. For instance, sentence (12) is an example of a time adverbial, whereas sentence (13) is an example of an adverbial of cause. In these examples, the connectors appear underlined:

(12) Saldré de casa [en cuanto me llames].

I will leave the house as soon as you call me.

(13) Sali de casa [porque me llamaste].

I left the house because you called me.

With adverbial clauses, the use of the proper connector is crucial, since this is the element that will allow us to assign the correct interpretation for the whole sentence. Editing of text generated by an OT may be useful in highlighting several phenomena associated with adverbial clauses:

i) the use of clause connectors,

ii) the use of non-finite verbs in English, in cases where Spanish would require a conjugated verb, and

iii) the selection of mood (indicative or subjunctive) of the subordinate verb in Spanish

As an example of the first point, consider sentences (14) and (15):

(14) a. As dogs get older, their hearing could start to go as well.

b. Como los perros envejecen, su audición podría empezar a ir también.

c. A medida que los perros envejecen

(15) a. Police were ordered to stand down as the city burnt.

b. Policía recibieron la orden de retirarse como la ciudad quemada.

c. La policía recibió la orden de retirarse mientras la ciudad ardía.

The particle as may be used in English to introduce a manner adverbial clause or to express cause or reason. It may however also be used to express a temporal relation (in a time adverbial clause). The translation of this particle into Spanish would be different depending on the type of adverbial relation that is established between the adjunct and the main predicate. Consequently, in order to provide a correct translation, it is crucial to identify what is the meaning relation that is established in a particular case. Thus, as may be translated as como, when it expresses a manner or causal relation, but not when it describes a temporal relation. This is the case in both (14) and (15), where an appropriate translation could be $a$ 
medida que, or mientras. In both cases the OT has erroneously identified como as the equivalent of as. Editing of these outputs requires that students become aware of different type of meaning relations established by different connectors, and how these meaning relations can be established in Spanish.

Another interesting example is illustrated in (16):

(16) a. But since Ripley proved there was a mainstream appetite for diverse types of female roles, there have been an increasing number of groundbreaking characters expanding those traditional boundaries. (www.thedissolve.com, June 26, 2015)

b. Pero como Ripley demostró que había un apetito corriente principal para diversos tipos de papeles femeninos, ha habido un creciente número de personaje revolucionarios expandiendo esos límites tradicionales.

c. Pero desde que Ripley demostró que había un anhelo por tener diferentes tipos de papeles femeninos.

The expression since may be used to express a temporal or a causal relation in English. In the example above, it is most natural to interpret the underlined clause as a time adverbial. However, in the translation generated it is translated as como. Como may introduce a cause adverbial, but not a time adverbial in Spanish. In this case, an appropriate connector would be desde que.

The following examples illustrate problems that may arise in the translation of subordinate verbs in adverbial clauses. Consider first the case of (17):

(17) a. One day last week while going to work I saw a horse lying on the street and people were trying to help it up.

b. Un día la semana pasada, mientras que ir a trabajar vi un caballo tirado en la calle y la gente estaba tratando de ayudar a todo. c. Un día la semana pasada mientras iba al trabajo.

The underlined expression is a time adverbial clause, introduced by while, which is correctly translated as mientras. However, as in certain nominal complements, the verb in English appears in a non-finite form, whereas in Spanish it needs to be conjugated.

The underlined expression in (18) illustrates a time adverbial clause, introduced by until. Notice that in this case the subordinate verb in Span- 
ish must appear in the subjunctive mood, since the clause denotes a future event. The OT translates the verb as an infinitive in Spanish, resulting in an ungrammatical sentence. Interestingly, there is a similar adverbial clause at the end of the sentence that is translated correctly as a subjunctive in Spanish:

(18 a. I will not know for sure until I book the flight, which cannot be done until final payment is received.

b. No lo sabré con seguridad hasta que reservar el vuelo, que no se puede hacer hasta que se reciba el pago final.

c. hasta que reserve el vuelo

Example (19) also shows a mistake in the translation of the mood of the verb of a subordinate conditional clause:

(19) a. Itchy children probably had lice for three weeks to two months by the time they're sent to the nurse. Classmates already would have been exposed. There's little additional risk of transmission, she says, if the student returns to class for a few hours until the end of the day. (San Jose Mercury News, Nov. 8, 2013)

b. Los niños con comezón probablemente tenían piojos durante tres semanas a dos meses por el tiempo que sean enviados a la enfermería. Los compañeros de clase ya se han expuesto. Hay poco riesgo adicional de transmisión, dice, si el estudiante regrese a clase durante unas horas hasta el final del día.

c. si el estudiante regresa a casa durante unas horas hasta el final del día.

This example also illustrates a relatively common mistake made by advanced students of Spanish: the use of the present subjunctive mood in a conditional introduced by the particle si. In this case, the verb regresar should appear in the indicative mood, since the condition is presented as possible.

\section{Classroom Activities and Learner Experience}

After learning about the structures above, foreign language teachers can use faulty OT output in creating advanced-level grammar activities. These activities could ask learners to: (a) edit the output (a portion of the output would be underlined indicating the error; the original text in English 
would also be presented), and (b) explain the correction. In explaining the correction, learners would also need to identify the type of subordinate clause and the differences between English and Spanish that help to explain the error. Lastly, learners would also be asked an extension type of question, such as to provide additional examples in English that would pattern similarly (and to provide correct Spanish translations). Table 1 below shows a sample template for possible classroom activities related to the three structures discussed above.

\section{Table 1. Classroom Activities Using OTs for Nominal, Relative, and Adverbial Clauses}

\begin{tabular}{|c|c|c|c|}
\hline & Nominal Clauses & Relative Clauses & Adverbial Clauses \\
\hline $\begin{array}{l}\text { Example } \\
\text { sentences }\end{array}$ & $\begin{array}{l}\text { We got into a taxi and } \\
\text { asked the taxi driver } \\
\frac{\text { to drive as quickly as }}{\text { he could. }} \\
\text { Metimos en un taxi y } \\
\text { le pedimos al taxista } \\
\text { que conducir tan rápi- } \\
\text { do como pudo. }\end{array}$ & $\begin{array}{l}\text { You've got to find a } \\
\text { doctor you feel most } \\
\text { comfortable with. }\end{array}$ & $\begin{array}{l}\text { Policía recibieron la } \\
\text { orden de retirarse } \\
\text { como la ciudad que- } \\
\text { mada. }\end{array}$ \\
\hline $\begin{array}{c}\text { Shared } \\
\text { activities }\end{array}$ & \multicolumn{3}{|c|}{$\begin{array}{l}\text { i) Correct the translation of the underlined part. } \\
\text { ii) Explain the corrections you have made. In the explanation refer to } \\
\text { the type of subordinate construction illustrated and discuss the rele- } \\
\text { vant differences in English and Spanish. }\end{array}$} \\
\hline $\begin{array}{l}\text { Extension } \\
\text { activities }\end{array}$ & $\begin{array}{l}\text { iii) Think of other } \\
\text { verbs in English (at } \\
\text { least 3) that enter into } \\
\text { the pattern illustrat- } \\
\text { ed in the example and } \\
\text { give examples with } \\
\text { the translation into } \\
\text { Spanish. }\end{array}$ & $\begin{array}{l}\text { iii) What other rel- } \\
\text { ative pronouns can } \\
\text { you use in this case in } \\
\text { Spanish? }\end{array}$ & $\begin{array}{l}\text { iii) What other con- } \\
\text { nector in Spanish can } \\
\text { be used in this exam- } \\
\text { ple? }\end{array}$ \\
\hline
\end{tabular}


As noted earlier, these types of activities have been carried out by the second author in his advanced-level Spanish grammar classroom. Anecdotally, the experience using these activities has been positive. Students are generally successful in identifying the source of the problem in the OT output. This in turn leads them to recognize a particular grammatical pattern in English and its equivalent construction in Spanish, thereby contributing to raising their metalinguistic awareness. In fact, informal comments made by students indicate that they indeed find the activities useful, particularly in raising their awareness of how Spanish (L2) works and the differences of grammatical patterns in English (L1) and in Spanish (L2). Furthermore, students' reactions suggest that they enjoy these activities and that they appreciate the fact that the tasks to perform are very specific and related to the particular grammatical constructions that are being discussed in class. They sometimes even find the mistakes produced by the OT to be comical, which increases their engagement level with the activity.

An important point to add is that similar exercises may also be devised to use in the classroom at different levels of Spanish. For example, activities that involve the correction of vocabulary and agreement mistakes (noun-adjective, subject-verb) may be used in beginner or intermediate courses (as illustrated in Correa, 2014). Furthermore, activities following the template in Table 1 above may be designed that focus on the OTs' output in Spanish for English phrasal and prepositional verbs (give up, run down, turn away, etc.), which may be used in beginner, intermediate, or advanced classes.

\section{CONCLUSION}

The purpose of this paper was to introduce specific uses of OTs for the advanced-level Spanish classroom, and to describe activities that could be carried out. This paper is therefore practical in nature, and it is the hope that it will help foreign language educators who teach advanced-level Spanish grammar courses with designing activities that utilize OTs. Specifically, teachers can use the faulty output produced by OTs in order to highlight and reinforce patterns of both the L2 (Spanish) and grammatical differenc- 
es between the L1 (English) and L2 (Spanish), particularly with respect to subordinate clauses. Moreover, since some students may ultimately acquire translation-oriented jobs, making students aware of patterns of mistakes in OT output may be important for their careers.

\section{REFERENCES}

Alderson, J. C., Clapham, C. \& Steel, D. (1997). Metalinguistic knowledge, language aptitude and language proficiency. Language Teaching Research, 1(2), 93-121.

Alipour, S. (2014). Metalinguistic and linguistic knowledge in foreign language learners. Theory and Practice in Language Studies, 4(12), 2640-2645.

Berg, E. C. (1999). The effects of trained peer response on ESL students' revision types and writing quality. Journal of Second Language Writing, 8(3), 215-241.

Bialystok, E. (1979). Explicit and implicit judgements of L2 grammaticality of L2 grammaticality. Language Learning, 29(1), 81-103.

Bialystok, E. (1981). The role of linguistic knowledge in second language use. Studies in Second Language Acquisition, 4(1), 31-45.

Burton, C. (2003). Idea: The online translator: Implementing national standard 4.1. Hispania, 86(2), 320-321.

Butt, J., \& Carmen, B. (2004). A new reference grammar of modern Spanish. New York, NY: McGraw-Hill.

Byrd, D. R. (2003). Practical tips for implementing peer editing tasks in the foreign language classroom. Foreign Language Annals, 36(3), 434-441.

Campos, H. (1993). De la oración simple a la oración compuesta. Washington, DC: Georgetown University Press.

Correa, M. (2011). Subjunctive accuracy and metalinguistic knowledge of L2 learners of Spanish. Electronic Journal of Foreign Language Teaching, 8(1), 39-56.

Correa, M. (2014). Leaving the "peer" out of peer-editing: Online translators as a pedagogical tool in the Spanish as a second language classroom. Latin American Journal of Content and Language Integrated Learning, 7(1), 1-20. 
French, J. R. (1991). Machine translation. In W. Brierley \& I. R. Kemble (Eds.), Computers as a tool in language teaching (pp. 55-69). Chichester, West Sussex: Ellis Horwood Limited.

Garcia, I. \& Pena, M. I. (2011). Machine translation-assisted language learning: writing for beginners. Computer Assisted Language Learning, 24(5), 471-487.

Hansen, J. G., \& Liu, J. (2005). Guiding principles for effective peer response. ELT Journal, 59(1), 31-38.

Kliffer, M. D. (2005). An experiment in MT post-editing by a class of intermediate/advanced French majors. In Proceedings of EAMT, $10^{\text {th }}$ Annual Conference (pp. 160-165). Budapest, Hungary.

Koike, D. A., \& Klee, C. A. Lingüística aplicada: Adquisición del español como segunda lengua. New York, NY: Wiley.

Larousse. (Eds.). (2010). Gramática lengua española: Reglas y ejercicios. México, DF: Larousse México.

Lundstrom, K., \& Baker, W. (2009). To give is better than to receive: The benefits of peer review to the reviewer's own writing. Journal of Second Language Writing, 18(1), 30-43.

Lunn, P.V., \& DeCesaris, J. A. (2006). Investigación de gramática. Boston, MA: Heinle Cengage Learning.

Luton, L. (2003). If the computer did my homework, how come I didn't get an "A"? The French Review, 76(4), 766-770.

National Standards in Foreign Language Education Project. (2015). Worldreadiness standards for learning languages. Alexandria, VA: Author.

Niño, A. (2008). Evaluating the use of machine translation post-editing in the foreign language class. Computer Assisted Language Learning, 21(1), 29-49.

Niño, A. (2009). Machine translation in foreign language learning: Language learners' and tutors' perceptions of its advantages and disadvantages. ReCALL, 21(2), 241-258.

O’Neill, E. M. (2012). The effect of online translators on L2 writing in French (Unpublished doctoral dissertation). University of Illinois at Urbana-Champaign, Urbana, IL. 
Renou, J. (2001). An examination of the relationship between metalinguistic awareness and second-language proficiency of adult learners of French. Language Awareness, 10(4), 248-267.

Richmond, I. M. (1994). Doing it backwards: Using translation software to teach target-language grammaticality. Computer Assisted Language Learning, 7(1), 65-78.

Roehr, K. (2007). Metalinguistic knowledge and language ability in university-level L2 learners. Applied Linguistics, 29(2), 173-199.

Shei, C.-C. (2002). Teaching MT through pre-editing: Three case studies. In Proceedings of the $6^{\text {th }}$ EAMT Workshop Teaching Machine Translation (pp. 89-98). Manchester, UK: EAMT.

Somers, H. (2003). Machine translation in the classroom. In H. Somers (Ed.), Computers and translation. A translator's guide (pp.319-340). Amsterdam/Philadelphia: Benjamins.

Whitley, M. S., \& González, L. (2007). Gramática para la composición. Washington, DC: Georgetown University Press.

Williams, L. (2006). Web-based machine translation as a tool for promoting electronic literacy and language awareness. Foreign Language Annals, 39(4), 565-578. 